DOI https://doi.org/10.18551/rjoas.2020-11.18

\title{
ADAPTATION OF NINE NEW INDONESIAN IMPROVED SOYBEAN VARIETIES IN PADDY FIELDS OF CENTRAL LOMBOK, INDONESIA
}

\author{
Herawati Nani, Erawati Baiq Tri Ratna, Aisah Ai Rosah, \\ Sugianti Titin, Hidayah Baiq Nurul ${ }^{\star}$ \\ Indonesian Agency for Agricultural Research and Development (IAARD) - \\ Institute for Assessment of Agricultural Technology (Balai Pengkajian Teknologi Pertanian), \\ West Nusa Tenggara Province, Indonesia \\ ${ }^{\star}$ E-mail: baignurul@pertanian.go.id
}

\begin{abstract}
Soybean (Glycine max L.) is one of the Indonesian most important agricultural commodities which contain high protein and become a raw material for various processed foods such as tofu, tempeh, soy milk, soy sauce, and bean sprouts. Recently, Indonesian soybean production has not been able to meet domestic needs; therefore, it still relies on importation. The main obstacle of soybean production in Indonesia is low productivity. One of the efforts to increase productivity is through the use of new improved varieties. This research aims to investigate the adaptation of nine new Indonesian improved soybean varieties in paddy fields of Central Lombok, West Nusa Tenggara Province, Indonesia. The research was conducted in July - October 2019 using a non-factorial randomized block design with the treatment of nine new improved soybean varieties namely Dega 1, Deja 1, Demas, Dena 1, Devon 2, Devon 1, Burangrang, Anjasmoro, and Detap. Each variety was replicated four times. Plant performances were observed during the vegetative phase and just before harvest which included plant height, number of branches, number of leaves, number of segments, and number of clumps. While the observed yield components were included the number of pods, weight of 100 grains, and soybean productivity. The results showed that during the vegetative phase, the highest plant height was produced by the variety of Devon 1, the highest number of branches was produced by Burangrang variety, the highest number of leaves and segments were produced by Anjasmoro variety. While during the generative phase, soybean varieties had a significant effect on plant height parameters with the highest value owned by Deja 1 variety. For the yield components, Demas variety produced the greatest number of filled pods, then the highest weight of 100 grains was produced by Dega 1 variety, and the highest productivity was achieved by Dena 1 variety.
\end{abstract}

\section{KEY WORDS}

New improved varieties, paddy fields, soybean.

Soybean (Glycine max L.) is one of the Indonesian most important agricultural commodities which contain high protein and become a raw material for various processed foods such as tofu, tempeh, soy milk, soy sauce, and bean sprouts. Recently, Indonesian soybean production has not been able to meet domestic needs; therefore, it still relies on importation. The main obstacle of soybean production in Indonesia is low productivity (Kementerian Pertanian, 2018). Meanwhile, some governmental efforts to increase soybean production include increasing planting area, use of new improved varieties as well as use of certified seeds. Soybean can be grown in paddy fields or dry land and do not require a lot of water. Soybean planting in paddy fields is generally conducted in the dry season (DS) I and II, and on dry land in the rainy season (RS) (Zakaria, 2010).

Mahdi and Suharno (2019) stated that the national soybean consumption has increased every year, which is due, among others, to the high public demand to meet the need for vegetable protein, an increase in population and public awareness of health. Nasmiati et al. (2014) explained that the government continues to strive and control the availability of food so that the food needs of the community or agro-industry can be met. According to Wahyuningsih (2019), national soybean production in 2018 amounted to 982.60 
thousand tons, while direct consumption reached 1.99 million tons. This causes the fulfillment of soybean needs through imports.

Constraints in soybean production, in addition to reduced interest from farmers, also limited land area. Therefore, intensification of soybean cultivation needs to be done, among others, by using new improved varieties. New improved soybean varieties have not been widely used by farmers due to limited information and availability. Meanwhile, Susanto and Nugrahaeni (2017) stated that until 2016 the Indonesian government has released 83 new improved soybean varieties. The newest varieties released in $2014-2016$ were included Demas 1, Dena 1, Dena 2, Devon 1, Dega 1, Deja 1 and Deja 2.

West Nusa Tenggara (WNT) Province is one of the soybeans producing areas in Indonesia with development centers, among others, in Central Lombok Regency. It is the third soybean producing area in Indonesia after East Java and Central Java Provinces with cultivation in paddy fields (58\%) and dry land (42\%) (Krisdiana, 2014). Several new improved soybean varieties that have been grown in Central Lombok Regency were Dega 1 (Herawati et al., 2019), Dena 1 and Devon 1 (Aisah et al., 2020), while the varieties that have been known for long time in WNT Province were included Anjasmoro, Wilis, Argomulyo, and Grobogan (Krisdiana, 2014). The existence of new improved soybean varieties is expected to increase soybean production and provide farmers with options to grow soybeans based on the advantages of each variety. Therefore, in this study, an adaptation of nine new improved soybean varieties was conducted in paddy fields that had never been planted with soybeans to observe the growth and yield of those nine new improved soybean varieties.

\section{MATERIALS AND METHODS OF RESEARCH}

The field experiment was conducted in dry season II on farmers' paddy fields, starting from July to October 2019 at Langko Village, Janapria District, Central Lombok Regency, WNT Province (Figure 1). The paddy fields have a rice- rice-tobacco cropping pattern and were not previously planted with soybeans. The experiment was conducted using a nonfactorial randomized block design, with the treatment of nine new improved soybean varieties namely Dega 1, Deja 1, Demas, Dena 1, Devon 2, Devon 1, Burangrang, Anjasmoro, and Detap. Each variety was replicated four times resulting in 27 experimental plots. The location of the field experiment is shown in Figure 1.

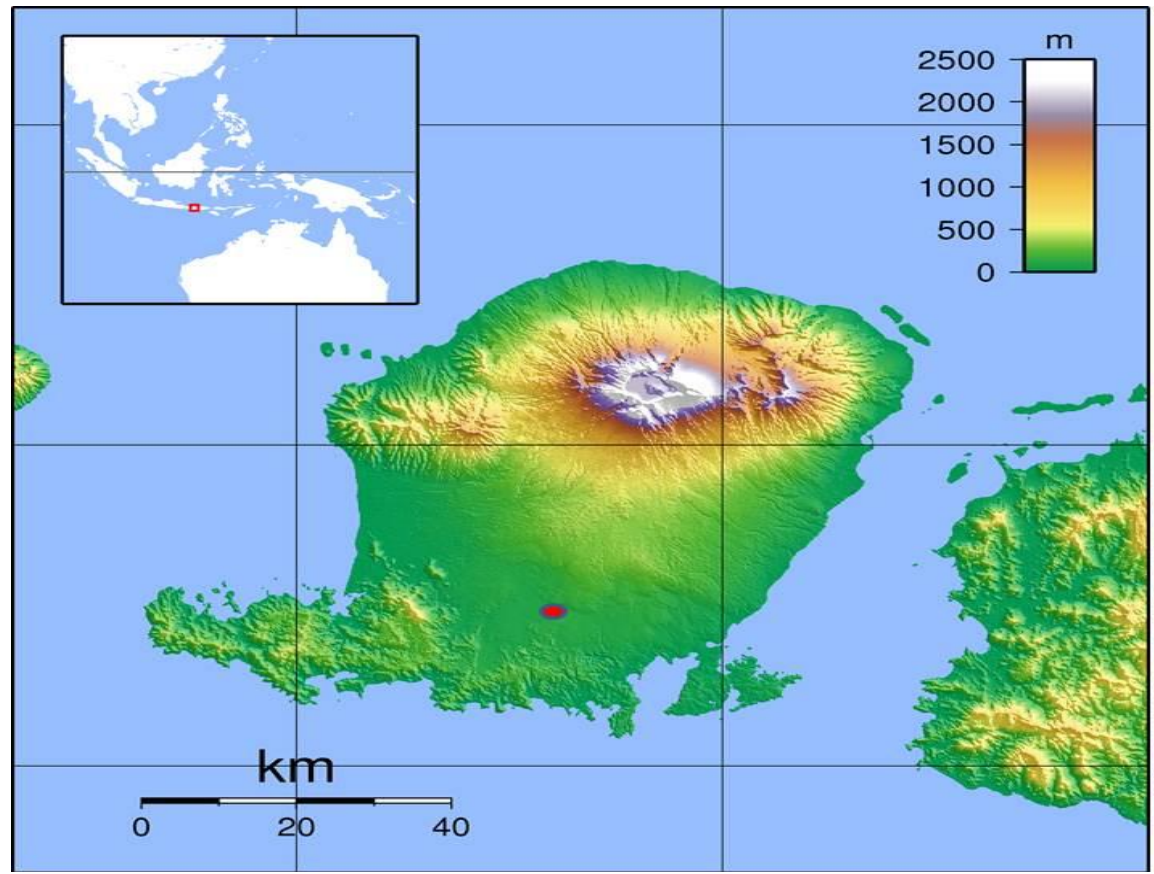

Figure 1 - Map of Lombok Island where the experimental site is in Langko Village of Central Lombok Regency with red dot sign on the lower part of the island 
Research activities include planting preparation, planting and maintenance, control of pest and disease, and harvesting. Preparation for planting was done without tillage. The former rice straw is left on the soil surface, then flattened. Planting was done by means of a hole with a depth of $2-3 \mathrm{~cm}$, each with two seeds per hole, spacing $15 \times 40 \mathrm{~cm}$. The seeds were given Agrisoy treatment before planting with a dose of $3 \mathrm{~g} / \mathrm{hole}$. Fertilization was applied using NPK at a dose of $100 \mathrm{~kg} / \mathrm{ha}$ and added with liquid fertilizer at a dose of one liter/ha. NPK fertilizer was applied before the straw mulch was spread out, while liquid fertilizer was applied at the age of $20,30,45$, and 60 days after sowing (DAS). Irrigation was applied at flowering and filling of pods. Weeding was done 2-3 times and pest control was used chemically. Harvesting was conducted by pulling out the plants and their pods. This was done when $75 \%$ (minimum) of plant leaves begin to turn yellow, dry and fall off and the pod skin has turned brown. Tiles measuring $2.5 \times 2.5 \mathrm{~m}$ were made to determine soybean productivity.

Observation of plant diversity was carried out during the vegetative phase and at the time of harvest, with observation parameters including plant height, number of branches, number of leaves, number of segments, number of clumps, number of pods, weight of 100 grains, and soybean productivity. Data were taken from 10 sample plants to observe plant performances, while soybean yield component data were taken from sampling plots. Furthermore, the data obtained were analyzed for variance using the SAS 9.0 program. If there is a treatment that gives a real effect, then it is followed by Duncan's multiple hose test with a test level of $5 \%$.

\section{RESULTS AND DISCUSSION}

General conditions of the experimental site. The experimental site was a rainfed lowland at an altitude of $325 \mathrm{~m}$ above sea level (asl). According to data of Centre of Statistical Bureau (2018), Janapria sub-district of Central Lombok Regency has a fairly fertile soil structure therefore activities in the agricultural sector are very dominant in community economic activities. Results of the initial soil analysis of the experimental site is presented in Table 1.

Table 1 - Results of soil analysis of the experimental site prior to the experiment

\begin{tabular}{lllll}
\hline Parameter & Unit & Analysis Result & Method & Criteria \\
\hline $\mathrm{pH}-\mathrm{H}_{2} \mathrm{O}$ & - & 6.11 & pH-meter & Slightly acid \\
$\mathrm{N}-$ Total & $\%$ & 0.13 & Kjeldahl & Low \\
C-Organic & $\%$ & 1.70 & Walkey\&Black & Low \\
Texture of 3 Fraction & $\%$ & 36 & & \\
Sand & $\%$ & 56 & Hydrometer & \\
Dust & $\%$ & 8 & Hydrometer & Dusty loam \\
Clay & - & & Hydrometer & \\
Texture Class & $\mathrm{ppm}$ & 9.52 & & \\
$\mathrm{P}$ available & $\mathrm{ppm}$ & 38.71 & Morgan Wolf & High \\
K available & Cmol/kg & 30.22 & Morgan Wolf & High \\
Cation Exchange Capacity (CEC) & & AAS & High \\
\hline
\end{tabular}

Note: Based on guidelines of soil, fertilizer, and crops analysis (Indonesian Soil Research Institute, Bogor, 2009).

Table 1 shows that the $\mathrm{pH}$ of the experimental site is slightly acidic. According to Danu et al. (2015), soil pH is very influential in plant growth, such as the availability of nutrients, the formation of root nodules by rhizobium bacteria which are associated with $\mathrm{N}$ fixation of plants, as well as development and population growth activities of rhizobium. Based on the results of the soil analysis, information was obtained that the total $\mathrm{N}$ nutrient content was low. These results provide information that in the cultivation process, $\mathrm{N}$ fertilizer input is required to support soybean production in the field. The $\mathrm{N}$ element is needed by plants during the vegetative period so that the addition of $\mathrm{N}$ will help optimize plant vegetative growth, namely height growth and number of tillers (Rina, 2015). 
The $\mathrm{P}$ available and $\mathrm{K}$ available nutrients contained in high soil, the addition of $\mathrm{P}$ nutrients will strengthen the plant root system so that it can stimulate plant height growth (Wahyudin, 2017). K nutrients generally, paddy soil contains more $\mathrm{K}$ than dry land soils (Subandi, 2013). This is closely related to soil types and natural processes that determine input and output of $\mathrm{K}$ to and from land. Paddy fields generally have a flat topography and/or as a depositional area so that the main soil material is alluvial which is relatively fertile. In addition, irrigation water can also supply $\mathrm{K}$.

Data of C organic content in the soil is low, whereas according to Chairani (2013) that the application of organic matter, especially on acidic soils, can increase the efficiency of the $\mathrm{P}$ fertilizer application. Organic acids contained in organic fertilizers can act as chelating compounds for Al, so that P becomes more available. In general, it can be said that organic matter increases the availability of soil phosphorus, through its decomposition which produces organic acids and $\mathrm{CO}_{2}$.

The land CEC value of the research location was high. According to Hakim et al. (1986), the high CEC was influenced by the properties and characteristics of the soil, namely soil reaction or soil $\mathrm{pH}$, soil texture or amount of clay, types of clay minerals, organic matter, as well as liming and fertilization. The texture of the research soil is classified as dusty loam class; this is confirmed by the dust value of $56 \%$ of the sand and clay fraction.

Description of New Improved Soybean Varieties. Soybean varieties tested for adaptation were new improved soybean varieties which were released by Indonesian Legumes and Tuber Crops Research Institute (ILETRI) Malang, Indonesia. Descriptions of those new improved soybean varieties on several parameters are presented in Table 2.

Table 2 - Descriptions of some parameters of new improved soybean varieties used in the experiment during the growing season 2019

\begin{tabular}{|c|c|c|c|c|c|}
\hline Variety & Plant height $(\mathrm{cm})$ & Number of branches & Number of pods & Weight of 100 grain $(\mathrm{g})$ & Productivity (ton/ha) \\
\hline Dega 1 & 53 & $1-3$ & 29 & 22.98 & 3.82 \\
\hline Deja 1 & 527 & 3 & 36 & 12.9 & 2.39 \\
\hline Demas & 66.3 & $4-6$ & 64 & 13 & 1.7 \\
\hline Dena 1 & 59 & $1-3$ & 29 & 14.3 & 1.7 \\
\hline Devon 1 & 58.1 & $2-3$ & 29 & 14.3 & 2.75 \\
\hline Devon 2 & 59.59 & 3-6 & 46 & 17.03 & 2.63 \\
\hline Burangrang & $60-70$ & $1-2$ & - & 17 & $1.6-2.5$ \\
\hline Anjasmoro & $64-68$ & $2.9-5.6$ & - & $14.8-15.3$ & $2.03-2.25$ \\
\hline Detap & 68.70 & 3 & 51 & 15.37 & 2.70 \\
\hline
\end{tabular}

Source: BALITKABI (ILETRI), 2016 and 2018.

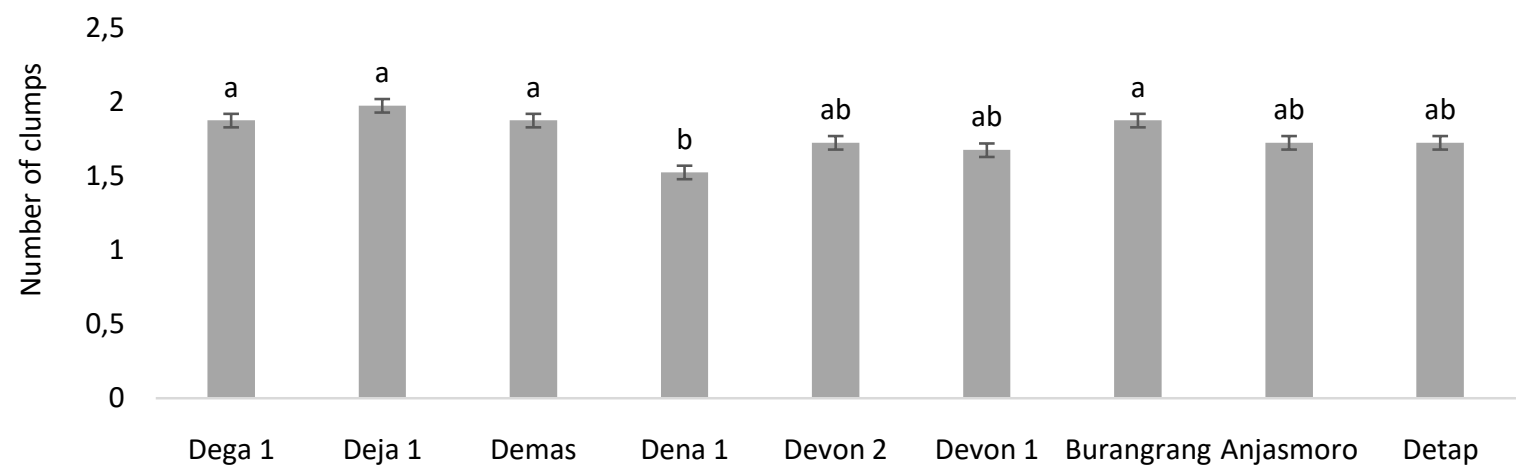

Soybean varieties

Figure 2 - Number of clumps of nine new improved soybean varieties in paddy fields of Central Lombok Regency during the early vegetative phase (3 weeks after sowing)

Early vegetative growth performances. The results of the analysis of variance show that new improved soybean varieties had a significant effect on all observed parameters 
during the early vegetative growth (3 weeks after sowing). Hakim (2017) stated that new improved soybean varieties that have been released by ILETRI generally have different genetic backgroundstherefore the morphological characteristics between varieties are often different.

Based on the results of the experiment, it was found that the highest number of clumps was in Deja 1 (2.0) because the total number of clumps growing was average 2, followed by Dega 1 (1.9) and Burangrang (1.9). The number of clumps will have a lot of influence on the number of plant populations, with the large number of clumps, the chances of producing the number of pods also increase (Figure 2).

Soybean varieties had a significant effect on plant height. The growth of soybean in the vegetative phase produced an average plant height of 14-18 cm (Figure 3), with the highest value produced by the Devon 1 variety, while the lowest was for the Demas variety. Based on the analysis of variance, the height of Devon 1 was only significantly different from Deja 1 and Demas varieties. The Deja variety that produces the highest value is different from other varieties. Meanwhile, the Dega variety with the lowest value was not different from Devon 1 and Devon 2. When compared with the new improved soybean varieties which were grown in West Lombok (Herawati and Aisah, 2019), Anjasmoro, Devon 1, Dena, Dega varieties produced better plant height values. The performance of soybean plants before harvest showed that the plant height varied with the highest value produced by Deja variety $(81.1$ $\mathrm{cm})$ and the lowest produced by Dega 1 variety $(46.6 \mathrm{~cm})$.

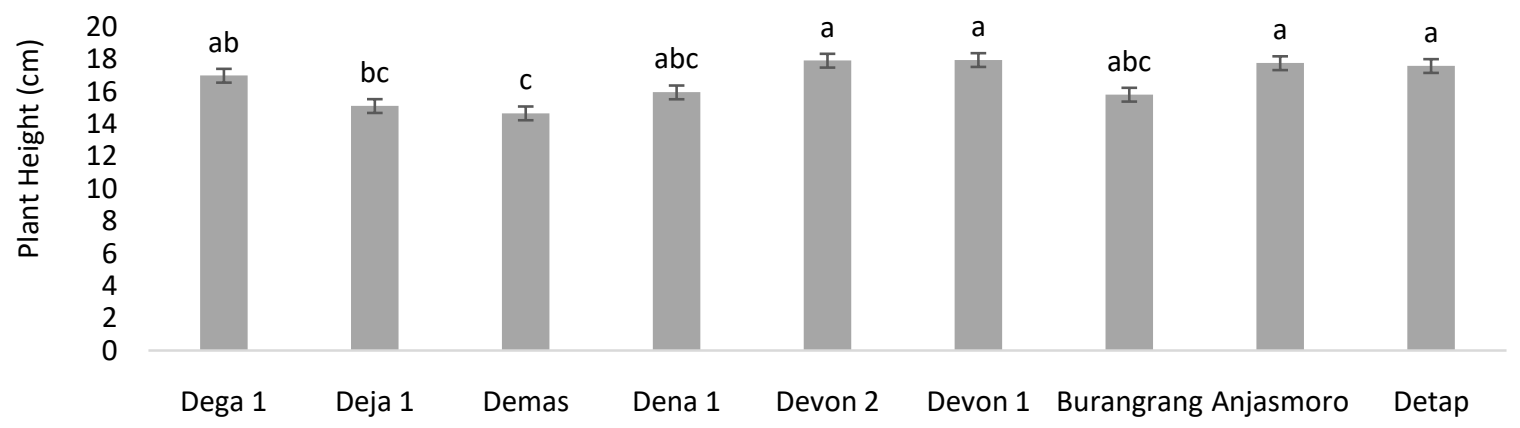

Soybean varieties

Figure 3 - Plant height of nine new improved soybean varieties in paddy fields of Central Lombok Regency during the early vegetative phase ( 3 weeks after sowing)

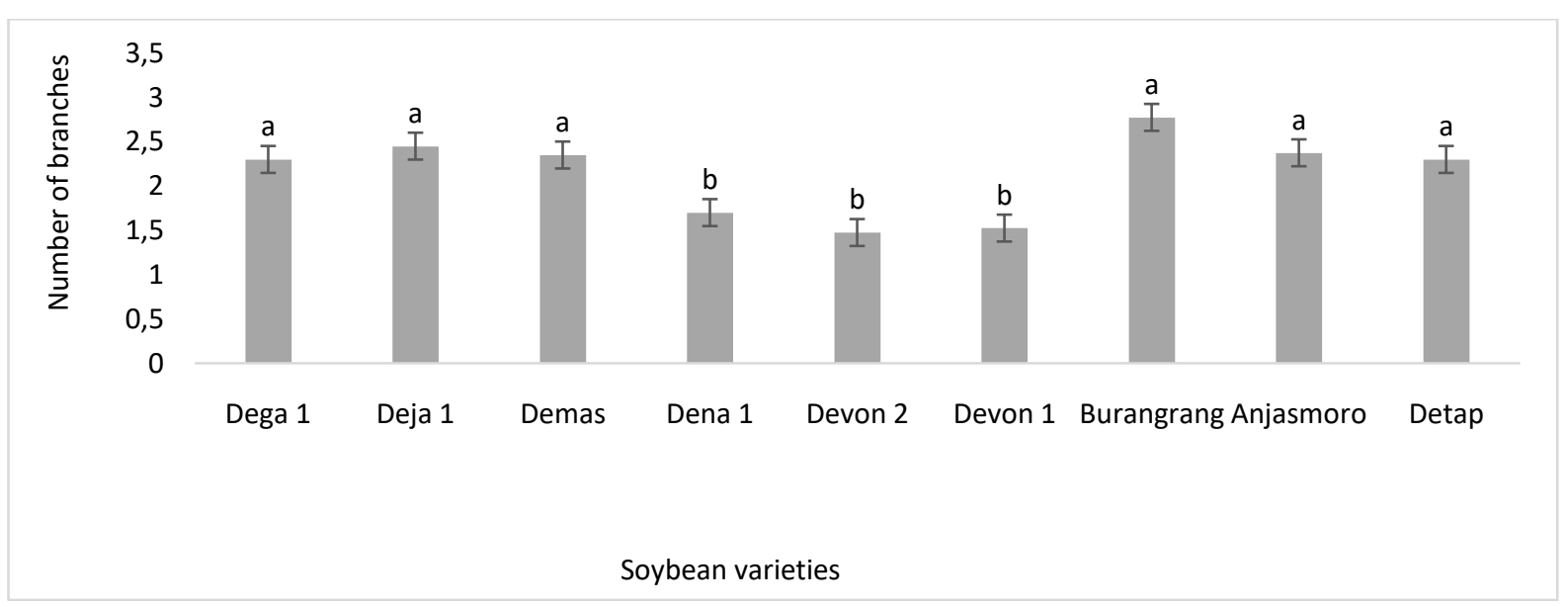

Figure 4 - Number of branches of nine new improved soybean varieties in paddy fields of Central Lombok Regency during the early vegetative phase (3 weeks after sowing) 
The highest number of branches was produced by the Burangrang variety (2.8), while the lowest was produced by the Devon 1 and Devon 2 varieties (1.5). Then for the number of branches, the Burangrang variety was significantly different from Dena 1, Devon 1, and Devon 2, but not different from other varieties (Figure 4).

Number of leaves of Anjasmoro variety was significantly different from Demas, Dena 1, Devon 1, Devon 2, and Burangrang varieties. Anjasmoro variety produced the highest values (3.3), while the lowest values for the number of leaves were produced by varieties Dena 1 (2.2) and Devon 2 (1.5) (Figure 5).

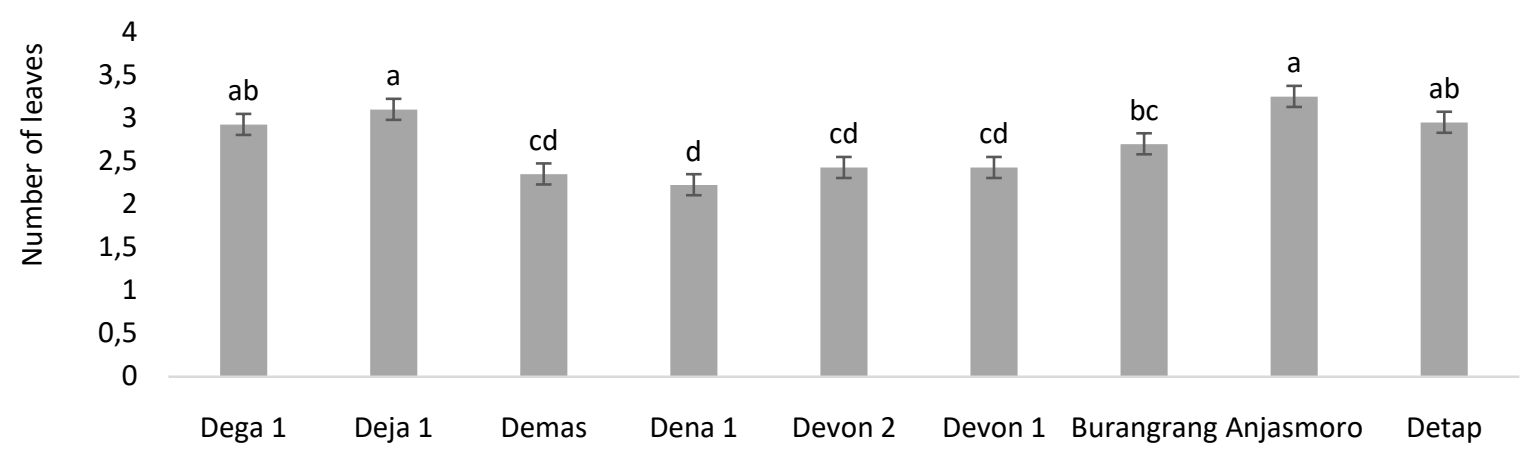

Soybean varieties

Figure 5 - Number of leaves of nine new improved soybean varieties in paddy fields of Central Lombok Regency during the early vegetative phase ( 3 weeks after sowing)

In the early vegetative phase, the highest number of nodus was in the Anjasmoro variety (3.3), followed by Dega 1 and Detap 1 with the number of nodus were 3.1 and 3.0 respectively (Figure 6). The number of nodus will have an effect on the potential for soybean pods to come out, the more nodus, the greater the chance of potential pods. The difference in the number of nodus is caused by genetic factors, varieties and light.

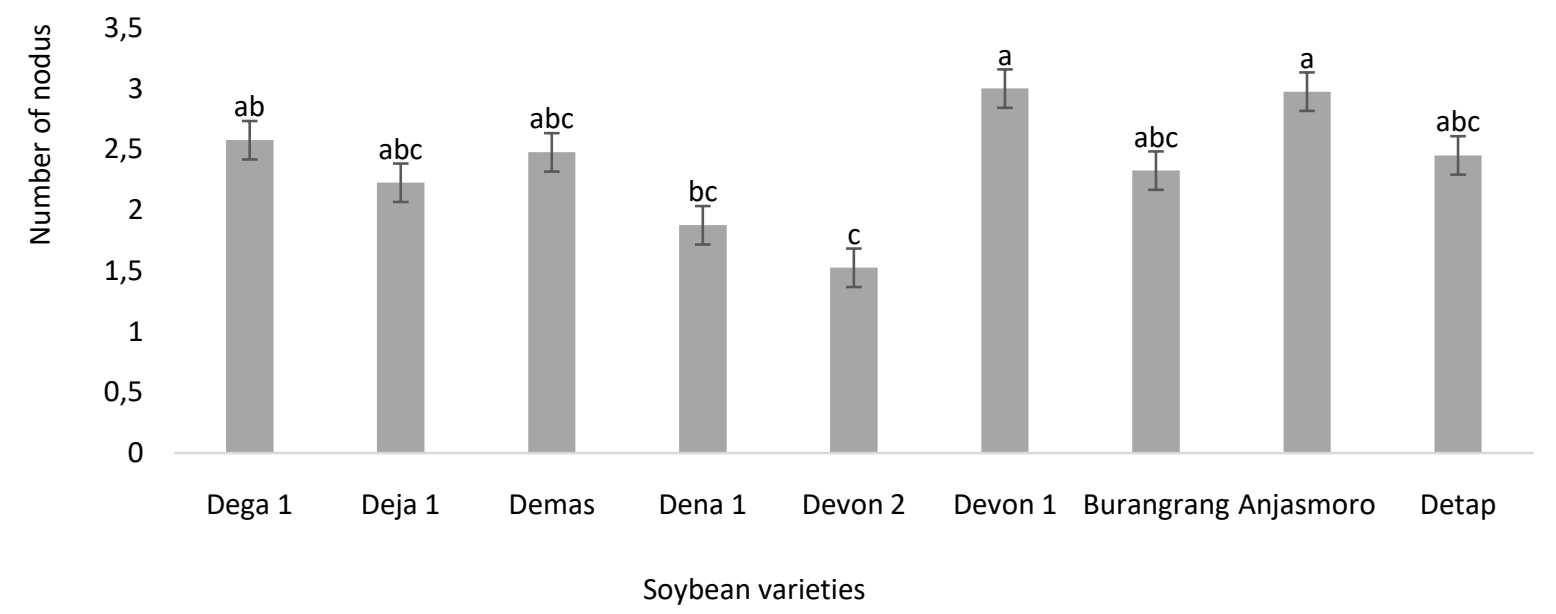

Figure 6 - Number of nodus of nine new improved soybean varieties in paddy fields of Central Lombok Regency during the early vegetative phase (3 weeks after sowing)

Generative and yield components. The highest number of pods was produced by Demas (46.6) followed by Detap (44.8) and Dena (43.6) varieties. Meanwhile the lowest number of pods was produced by Dega 1 (16.8), followed by Devon 1 (18.2) and Deja (34.8) (Figure 7). The nine varieties of soybean have a relatively low number of empty pods (0.2 1.7), so that the number of filled pods does not decrease much. 


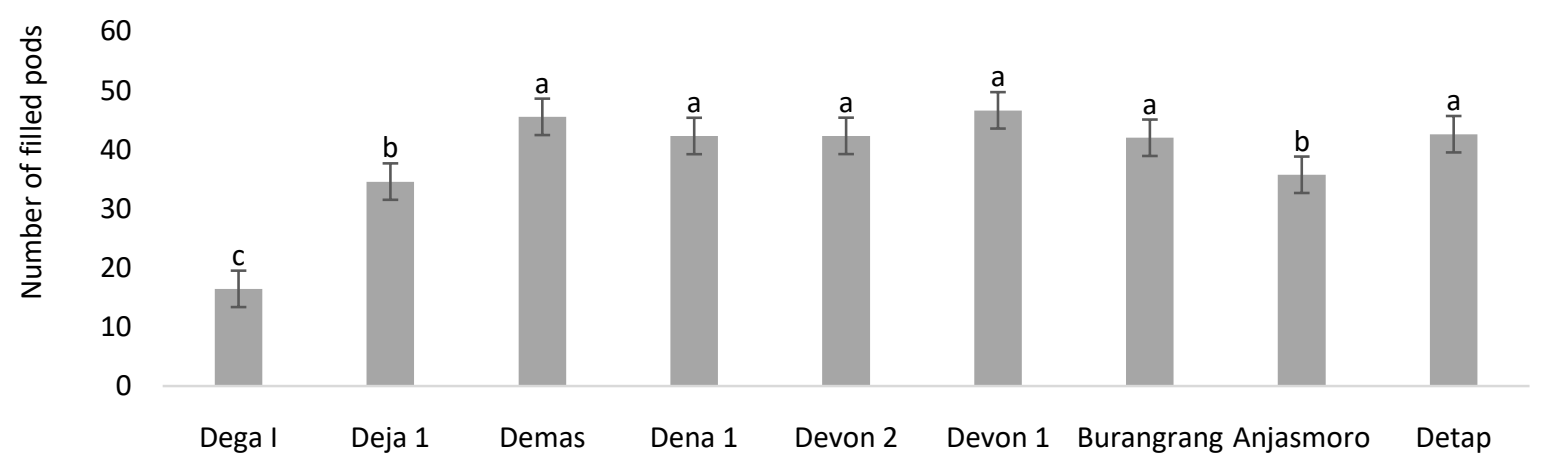

Soybean varieties

Figure 7 - Number of pods of nine new improved soybean varieties in paddy fields of Central Lombok Regency before harvesting

The varieties of soybean had a significant effect on the number of filled pods filled. The highest value was produced by the Demas variety, but it was not significantly different from the Detap, Devon, Dena 1, and Burangrang varieties. Meanwhile, the lowest value was produced by Devon 1 and Dega varieties, and it was different from other varieties. Pod is one of the important characters that can affect soybean yield. Research by Dwiputra et al. (2015) showed that the number of filled pods was significantly correlated with the number of branches, plant height, number of seeds, and seed weight per soybean plant, but the number of pods was not significantly correlated with the stem diameter and weight of 100 soybeans.

Weight of 100 grain

The weight of 100 grain indicates that Dega 1 variety produces the highest 100 grain weight (25.81) while the lowest was produced by Demas variety (10). Based on the analysis of variance, soybean varieties had a significant effect on the weight of 100 grains. As the producer of the highest 100 grain weight values, Dega 1 variety is different from the other eight varieties. Meanwhile, the Demas variety which produced the lowest 100 grain weight value was not significantly different from Detap (Figure 8). Different varieties and agroecological conditions can produce soybean seeds with different sizes. Adie and Krisnawati (2014) stated that the size of soybean grain between countries varies and large seed soybeans in Indonesia have a size of 14-16 grams/100 seeds.

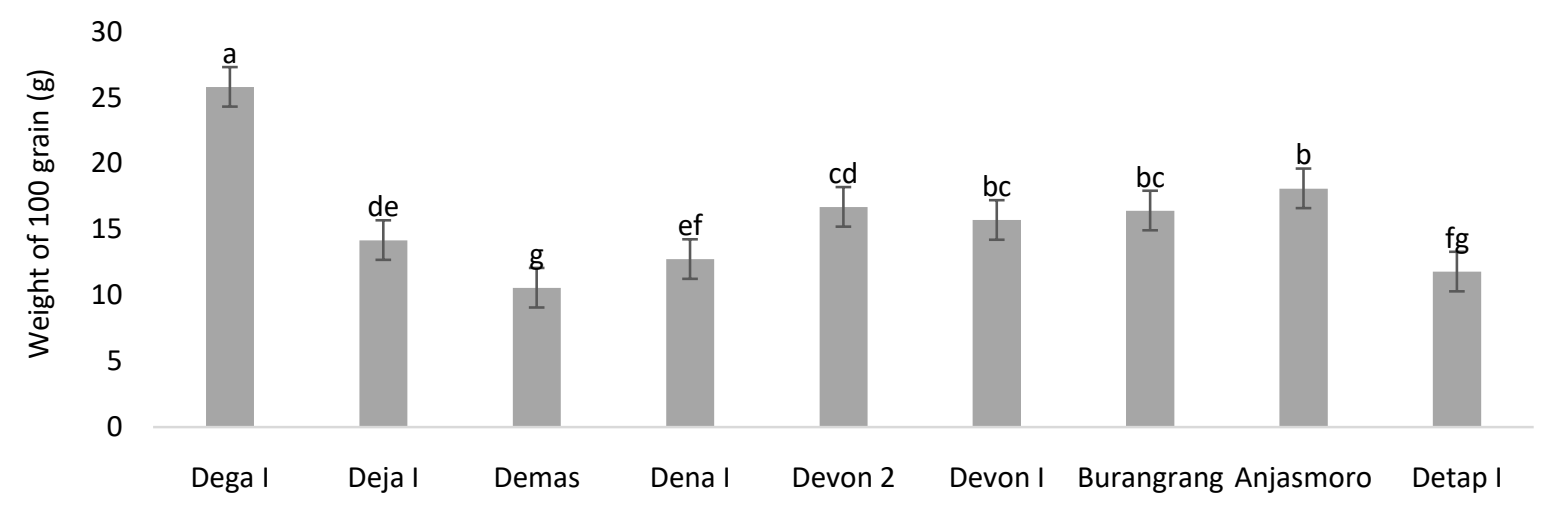

Soybean varieties

Figure 8 - Weight of 100 grain of nine new improved soybean varieties in paddy fields of Central Lombok Regency 
Soybean varieties had a significant effect on productivity. The highest value was produced by the Dena 1 variety $(2.6 \mathrm{ton} / \mathrm{ha})$, but it was not significantly different from the Deja 1 (1.9 ton/ha) and Demas (1.7 ton/ha) varieties. Meanwhile, the lowest productivity value was produced by Burangrang variety ( $0.8 \mathrm{ton} / \mathrm{ha})$ and was not different from other varieties except Dena 1 (Figure 9). When compared with the description of soybean from ILETRI (2016), the Dena 1 variety is close to its potential yield. This difference is caused by genetic differences and interactions between genetics and the environment. However, all new improved soybean varieties were adaptable to experimental site where soybeans had not been planted a few years earlier. The yields of Burangrang and Anjasmoro varieties were lower than Somantri et al. (2019), but slightly higher for Demas variety.

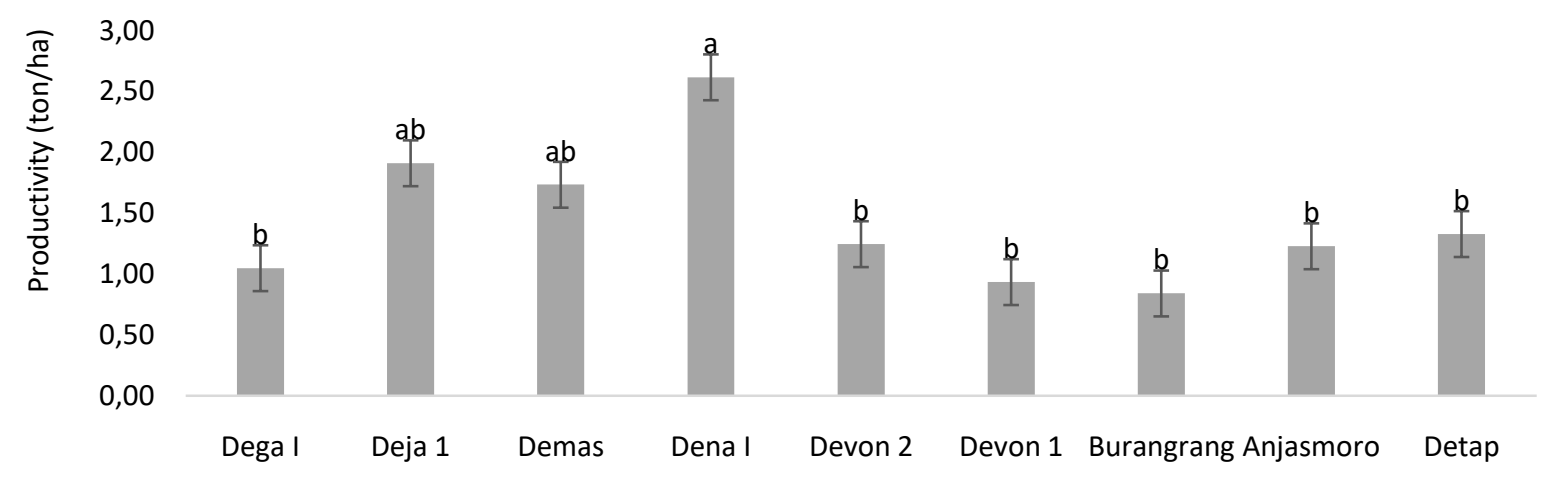

Soybean varieties

Figure 9 - Productivity of nine new improved soybean varieties in paddy fields of Central Lombok Regency

\section{CONCLUSION}

New improved soybean varieties had a significant effect on all observed parameters. The varieties that have been released generally have different genetic backgrounds, so that the morphological characters between varieties are often different. During the vegetative phase, the highest plant height was produced by the variety of Devon 1, the highest number of branches was produced by Burangrang variety, the highest number of leaves and segments were produced by Anjasmoro variety. While during the generative phase, soybean varieties had a significant effect on plant height parameters with the highest value owned by Deja 1 variety. For the yield components, Demas variety produced the greatest number of filled pods, then the highest weight of 100 grains was produced by Dega 1 variety, and the highest productivity was achieved by Dena 1 variety.

\section{CONFLICT OF INTERESTS}

Authors clearly declare that they have no competing interests.

\section{ACKNOWLEDGEMENTS}

We would like to thank the Indonesian Agency for Agricultural Research and Development (IAARD) for funding this research. In addition, we would like to express our gratitude to the Head of Institute for Assessment of Agricutural Technology (IAAT) West Nusa Tenggara Province at that time, Dr. Ir. M. Saleh Mokhtar, MP., for giving chance to the soybean team to conducted the field experiment during the financial year of 2019.

The first author was the main contibutor of this paper, while the second to the fifth authors were the supporting contributors. 


\section{REFERENCES}

1. Adie M. M., Krisnawati A. (2014). Keragaan hasil and komponen hasil biji kedelai pada berbagai agroekologi. Dalam Prosiding Seminar Hasil Penelitian Tanaman Aneka Kacang and Umbi Tahun 2013, 7 - 17. Pusat Penelitian and Pengembangan Tanaman Pangan, Badan Penelitian and Pengembangan Pertanian. (in Indonesian).

2. Aisah A. R., Herawati N., and Hidayah B. N. (2020). Growth and yield of five Indonesian new superior varieties of soybean in dry climate rainfed rice field. In The $3^{\text {rd }}$ International Conference on Biosciences. IOP Conf. Ser.: Earth Environ. Sci 457012054.

3. Balai Penelitian Tanaman Aneka Kacang and Umbi. (2016). Deskripsi Varietas Unggul Aneka Kacang and Umbi. 8th ed. Balai Penelitian Tanaman Aneka Kacang and Umbi, Malang. (in Indonesian).

4. Balitkabi (2016). Deskripsi Varietas Unggul Kedelai 1918 - 2016. Balai Penelitian Tanaman Aneka Kacang and Umbi. Badan Penelitian and Pengembangan Pertanian, Kementrian Pertanian Republik Indonesia. http://balitkabi.litbang.pertanian.go.id/wpcontent/uploads/2016/09/kedelai.pdf. diakses 29 September 2020 (in Indonesian).

5. Balitkabi (2018). Deskripsi varietas terbaru. Balai Penelitian Tanaman Aneka Kacang and Umbi. Badan Penelitian and Pengembangan Pertanian, Kementrian Pertanian Republik Indonesia.

6. http://balitkabi.litbang.pertanian.go.id/informasi/deskripsi-varietas-terbaru/ diakses 29 September 2020 (in Indonesian).

7. BPS (2019). Kecamatan Janapria dalam Angka 2018. Katalog:1102001.5202040. Badan Pusat Statistik Kabupaten Lombok Tengah (in Indonesian).

8. Chairani H. (2013). Pertumbuhan, Hasil, and Mutu Biji Kedelai dengan Pemberian Pupuk Organik and Fosfor. J. Agron. Indonesia 41 (3) : 209 - 214 (in Indonesian).

9. Dwiputra A. H., Indradewa D., Susial E.T. (2015). Hubungan komponen hasil and hasil tiga belas kultivar kedelai (Glycine $\max$ (L.) Merr.). Vegetalika, 4(3): 14-28. (in Indonesian).

10. Hakim N., Nyakpa M. Y., Lubis A. M., Nugroho S. G., Saul M. R., Diha M. A., Hong G. B., Bailey H. H. (1986). Dasar - Dasar Ilmu Tanah. Universitas Lampung. Lampung. (in Indonesian).

11. Hakim L. (2017). Komponen hasil and karakter morfologi penentu hasil kedelai pada lahan sawah tadah hujan. Penelitian Pertanian Tanaman Pangan, 1(1): 65-72. (in Indonesian).

12. Herawati N., Aisah A. R. (2019). Keragaan agronomis and produktivitas beberapa varietas unggul baru kedelai di lahan sawah beriklim kering. Dalam Prosiding Seminar Nasional and Rakernas Perhimpunan Agronomi Indonesia (Peragi) 2018, 403 - 408. Pusat Perpustakaan and Penyebaran Teknologi Pertanian, Bogor bekerjasama dengan Perhimpunan Agronomi Indonesia and Institut Pertanian Bogor. (in Indonesian).

13. Kementerian Pertanian. (2018). Produksi, luas panen, and produktivitas palawija di Indonesia 2014-2018. Diunduh $14 \quad$ Mei 2018 dari http://www.pertanian.go.id/Data5tahun/TPATAP-2017(pdf)/01-PalawijaNasional.pdf. (in Indonesian).

14. Kriasdiana R. (2014). Dinamika preferensi petani and penyebaran varietas ungggul kedelai di Provinsi Nusa Tenggara Barat. Buletin Palawija, 28:93-101. (in Indonesian).

15. Mahdi N. N., Suharsono. (2019). Analisis faktor-faktor yang mempengaruhi impor kedelai di Indonesia. Forum Agribisnis, 9(2): 160-184. (in Indonesian).

16. Nasmiati C., Ginting R., Rahman A. (2014). Analisis produksi and ketersediaan serta kebutuhan kedelai dalam kaitannya dengan ketahanan pangan di Provinsi Sumatera Utara. Agrica (Jurnal Agribisnis Sumatera Utara), 7(1): 13-27. (in Indonesian).

17. Rina D. (2015). Manfaat Unsur N, P, K bagi Tanaman. BPTP Kaltim, Badan Litbang Pertanian. https//kaltim.litbang.pertanian.go.id diakses 8 September 2018. (in Indonesian). 
18. Somantri R. U., Syahri, Thamrin T. (2019). Potensi hasil beberapa varietas unggul baru (VUB) kedelai di lahan kering Sumatera Selatan. Dalam Prosiding Seminar Nasional Lahan Suboptimal 2018, 473-481. Unsri Press, Palembang. (in Indonesian).

19. Subandi. (2013). Peran and Pengelolaan Hara Kalium untuk Produksi Pangan di Indonesia. Pengembangan Inovasi Pertanian Vol. 6 No. 1 Maret 2013: 1-10 (in Indonesian).

20. Wahyudin A. (2017). Respons tanaman kedelai (Glycine max L.) varietas Wilis akibat pemberian berbagai dosis pupuk $\mathrm{N}, \mathrm{P}, \mathrm{K}$, and pupuk guano pada tanah Inceptisol Jatinangor. Jurnal Kultivasi Vol. 16(2) Agustus 2017. Hal 333-339. (in Indonesian).

21. Zakaria A. K. (2010). Program pengembangan agribisnis kedelai dalam peningkatan produksi and pendapatan petani. Jurnal Litbang Pertanian, 29(4): 143-153. (in Indonesian). 